\title{
Mixing of Fly Ash with Coal Mine Overburden to Increase the Slope Stability
}

\author{
Kamlesh Sahu ${ }^{1}$, Pankaj Dewangan ${ }^{2}$ \\ ${ }^{1}$ Student, Dept. of Mining Engineering, National Institute of Technology, Raipur, C G, India \\ ${ }^{2}$ Head of Department, Dept. of Mining Engineering, National Institute of Technology, Raipur, C G, India
}

\begin{abstract}
Fly ash is mainly being utilized for making cement, bricks, concrete, roads and small quantity in mine void filling. The consumption of fly ash in construction activity has reached to almost saturation level and there is not much potential to consume more fly ash in these segments. Mining sector like mine void filling, underground stowing and mixing with overburden of open cast mine are the only potential area where bulk quantity of fly ash can be utilized so that $100 \%$ utilization target can be achieved. There are more than 165 opencast coal mines in India and many are near to thermal power stations. Opencast mining plays a major role in meeting the demand of coal for thermal power generation. The stability of overburden dumps stands at high priority from the safety and economic perspective. This paper investigates the suitability of fly ash to be disposed of by mixing it with overburden (OB) dumps to increase the slope stability in coal mines. This paper attempts to highlight the utilization of fly ash for slope stabilization of overburden during backfilling, in order to save our environment. This paper presents various open cast coal mine where fly ash has been successfully disposed in overburden dump material.
\end{abstract}

Keywords: Fly Ash Mixing, Backfilling, Open Cast Coal Mines, Overburden, Slope Stability

\section{Introduction}

Fly ash is a by-product material being generated by thermal power plants from combustion of Pulverized coal. High ash content is found to be in range of $30 \%$ to $50 \%$ in Indian coal [1]. There are two classes of fly ash: " $F$ " is made from burning anthracite and/or bituminous coal, and "C" is produced from lignite or sub bituminous coal. Fly ash has been considered as a "Polluting Industrial Waste" till about a decade back and was being disposed off in ash ponds occupying large areas of land [2]. India's coal is of poor quality with almost 40 percent ash, which means the plants burn $0.74 \mathrm{~kg} / \mathrm{kwh}$ of power generation which is 41 percent higher than the global average. Coal based power plants consumed 536.64 million tonnes of coal in 2015-16, which were around three fourth of the total coal used in the country. Fly ash was generated about 176.74MT and utilized approximate 107.76 MT i.e. levels of effort of fly ash utilization had resulted in achieving just $60.97 \%$ by year 2015-16[3].

In India, energy policy puts major emphasis on meeting energy demands through the thermal route and there has been a purposeful thrust towards producing coal from opencast mines. At one end Surface mining necessitates removal of considerable volume of overburden on the other end thermal plants using coal produce huge volume of fly ash. The problem is compounded in India where ash percentage in thermal grade coal is rather high. Fly ash disposal, its utilization and management has been a longstanding challenge for the Indian power sector. Making a more productive use of fly ash or its safe disposal would have considerable environmental benefits, whilst reducing both air and water pollution. Coal mine overburden material, which usually consists of a mixture of coarse-grained particles to rock fragments grading to fine-grained particles, causes geotechnical and environmental problems on random disposal. The overburden is highly heterogeneous. Gradation results suggest that fines and coarse grains are approximately equally represented in the soil reported by Ulusay et al. [4] CBR test result is considered as a standard measure to evaluate the suitability of any road building material. Although fly ash has found a number of uses such as manufacture of cement, concrete and construction materials, ceramics, road base construction and mineral filler in asphaltic mix [5,6] a major fraction still needs to be disposed of by land fill or similar purposes. It is therefore vital that new and feasible methods of disposal and utilization of fly ash must be explored.

\section{Properties of fly ash}

Fly ash is highly useful as a geo-technical material for construction of embankment and reclamation of low lying areas, filling of underground, open mines, use in agriculture and reclamation of degraded / waste lands, etc. The pozzolanic property coupled with lime reactivity makes it very suitable for cementitious / binding applications. Its geo-technical property makes it a good substitute of soil and the presence of required percentage of silica, alumina and iron oxide etc. makes it suitable for sintered applications [7]. The following tables provide general range of physical, chemical, geo-technical properties of fly ash [8].

Table 1: Physical properties of fly ash

\begin{tabular}{|c|c|}
\hline Parameters & Fly Ash \\
\hline Bulk Density (gm/cc) & $0.9-1.3$ \\
\hline Specific Gravity & $1.6-2.6$ \\
\hline Plasticity & Lower or non-plastic \\
\hline Shrinkage Limit (Vol stability) & Higher \\
\hline Grain size & $\begin{array}{c}\text { Major fine sand / silt and small } \\
\text { per cent of clay size particles }\end{array}$ \\
\hline Clay (percent) & Negligible \\
\hline Free Swell Index & Very low \\
\hline Classification (Texture) & Sandy silt to silty loam \\
\hline $\begin{array}{c}\text { Water Holding Capacity } \\
\text { (WHC) (per cent) }\end{array}$ & $40-60$ \\
\hline
\end{tabular}


International Journal of Science and Research (IJSR)

ISSN (Online): 2319-7064

Index Copernicus Value (2016): 79.57 | Impact Factor (2015): 6.391

\begin{tabular}{|c|c|}
\hline Porosity (per cent) & $30-65$ \\
\hline Surface Area $(\mathrm{m} 2 / \mathrm{kg})$ & $500-5000$ \\
\hline Lime reactivity $(\mathrm{MPa})$ & $1-8$ \\
\hline
\end{tabular}

Above properties are just approximation values which are depending on the types of fly ash.

Table 2: Chemical composition of fly ash and pond ash

\begin{tabular}{|c|c|c|}
\hline Compounds (\%) & Fly Ash & Pond Ash \\
\hline $\mathrm{SiO} 2$ & $38-63$ & $37-75$ \\
\hline $\mathrm{A} 2 \mathrm{O} 3$ & $27-44$ & $11-53$ \\
\hline $\mathrm{TiO} 2$ & $0.4-1.8$ & $0-1$ \\
\hline $\mathrm{Fe} 2 \mathrm{O} 3$ & $3.3-6.4$ & $3-34$ \\
\hline $\mathrm{MnO}$ & b.d-0.5 & b.d-0.6 \\
\hline $\mathrm{MgO}$ & $0.01-0.5$ & $0.1-0.8$ \\
\hline $\mathrm{CaO}$ & $0.2-8$ & $0.2-0.6$ \\
\hline $\mathrm{K} 2 \mathrm{O}$ & $0.04-0.9$ & $0.1-0.7$ \\
\hline $\mathrm{Na} 2 \mathrm{O}$ & $0.07-0.43$ & $0.05-0.31$ \\
\hline $\mathrm{LOI}$ & $0.2-5.0$ & $0.01-20.0$ \\
\hline $\mathrm{pH}$ & $6-8$ & $6-8$ \\
\hline
\end{tabular}

bd: below detection limit, LOI: Loss on Ignition

Above properties are just approximation values which are depending on the types of fly ash.

Table 3: Geo-technical properties of fly ash

\begin{tabular}{|c|c|}
\hline Parameter & Range \\
\hline Specific Gravity & $1.6-2.6$ \\
\hline Plasticity (per cent) & Lower or Non-Plastic \\
\hline Maximum Dry Density (gm/cc) & $0.9-1.3$ \\
\hline Optimum Moisture Content (per cent) & $18.0-38.0$ \\
\hline Cohesion (kN/m2) & Negligible \\
\hline Angle of Internal Friction(degrees) & $30-40$ \\
\hline Coeff. Of consolidation Cv(cm2/Sec) & $1.75 X 10-5-2.01 \mathrm{X} 10-3$ \\
\hline Compression index Cc & $0.05-0.4$ \\
\hline Permeability (cm/sec) & $8 \mathrm{X} 10-6-7 \mathrm{X} 10-4$ \\
\hline Particle size Distribution & \\
(per cent of materials) & $1-10$ \\
Clay size fraction & $8-85$ \\
Silt size fraction & $7-90$ \\
Sand size fraction & $0-10$ \\
Gravel size fraction & $3.1-10.7$ \\
\hline Coefficient of Uniformity & \\
\hline
\end{tabular}

\section{Slope Stability}

Due to continuous increase in dump heights there is a possible threat of their stability and related problems. Slope stability is the stability of the benches of the working face or it may be the overburden dump lying at certain angle with the horizontal. The stability of the slope comes from the fact that when the resisting forces like cohesion exceeds the driving forces like presence of water, seismic activities, and many more, then bench is said to be stable otherwise slope failure occurs. The practical approach to slope stability is guided by various geo-technical parameters and a good measure of engineering judgment. Slope stability depends on the shear strength of the material existing along such surface and their orientation related to the slope. Shear strength properties are product of cohesiveness of the particles(C) and friction angle $(\varnothing)$ that is present along joint surface that is depends on the mechanical and functional characteristic of the surface. OB dump materials where sandstone is the main composite material has very less value for coefficient of internal friction (0.51), angle of internal friction (26.6), cohesion(28) thus have tendency to be easily unsterilized[9].
Following factors are affecting in slope failure showing in table-4.

- Geological discontinuities of Rock Mass

- Geo-technical Properties of slope

- Groundwater and Rainfall

- Slope's Geometry

- State of stress

- Surface erosion due to flow of the water

- Seismic effect i.e forces due to earthquakes

- Dynamic Forces due to Blasting

- Movement of the Heavy Earth Moving Machinery

- Modification in the Slope like Under cutting

- Temperature and Spontaneous Heating

- Presence of underground galleries

Table 4: factors are affecting in slope failure

\begin{tabular}{|c|c|c|}
\hline No & $\begin{array}{c}\text { Name of the parameters } \\
\text { and properties }\end{array}$ & Details \\
\hline 1 & Geological Discontinuities & Fault, bedding plane, joint \\
\hline 2 & Water & $\begin{array}{c}\text { Ground water, rainfall, aquifer, } \\
\text { permeability, drainage pattern, }\end{array}$ \\
\hline 3 & Strength & $\begin{array}{c}\text { Shear strength, tensile strength, } \\
\text { compressive strength }\end{array}$ \\
\hline 4 & Geotechnical parameters & $\begin{array}{c}\text { Gran size, atterberg limit, } \\
\text { moisture content }\end{array}$ \\
\hline 5 & Method of construction & $\begin{array}{c}\text { Shovel, BWE, dumper, or } \\
\text { combination }\end{array}$ \\
\hline 6 & Dynamic forces & Blasting, Seismic activity \\
\hline 7 & Geometry of slope & $\begin{array}{c}\text { Bench height and angle, Height } \\
\text { and angle of slope }\end{array}$ \\
\hline
\end{tabular}

\section{Type of Slope Failures}

Slope failures are major natural hazards that occur in many areas throughout the world. Slopes expose two or more free surfaces because of geometry. Plane, wedge, toppling, rockfall and circular types of failure are common in slopes (Figure 1). The first four are more predominant in rock slopes and can be primarily controlled by the orientation and the spacing of discontinuities planes with respect to the slope face. The pattern of the discontinuities may be comprised of a single discontinuity or a pair of discontinuities that intersect each other, or a combination of multiple discontinuities that are linked together to form a failure mode. Circular and non circular failure occurs in mine dump, soil, fractured rock mass or heavily jointed and very weak rock. The types of slope failure are primarily controlled by water content, material properties and foundation strength.
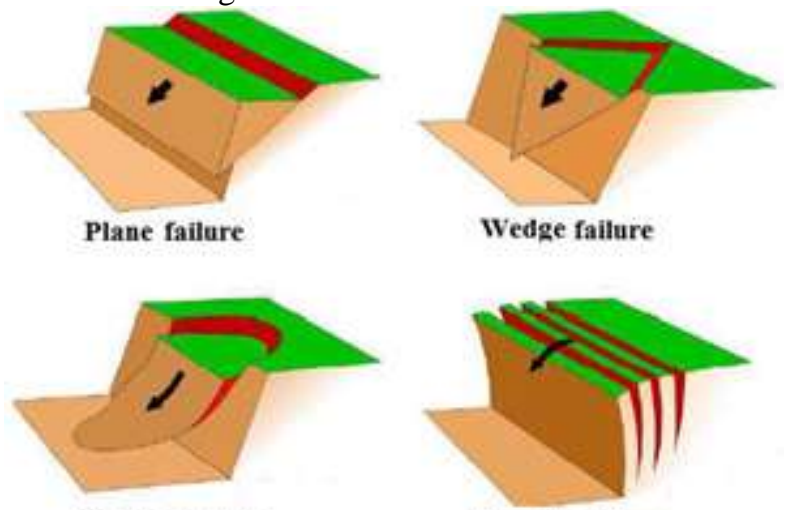

Circular failure

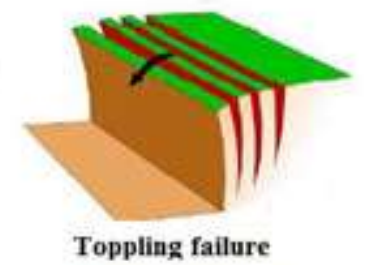

Figure 1: Common types of slope failure

Volume 6 Issue 12, December 2017 www.ijsr.net

Licensed Under Creative Commons Attribution CC BY 


\section{International Journal of Science and Research (IJSR) \\ ISSN (Online): 2319-7064}

Index Copernicus Value (2016): 79.57 | Impact Factor (2015): 6.391

\subsection{Plane Failure}

A planar failure of $\mathrm{OB}$ slope occurs when a mass of rock in a slope slides down along a relatively planar failure surface. The failure surfaces are usually structural discontinuities such as faults, joints, bedding planes or the interface between bedrock and an overlying layer of weathered rock. Block sliding along a single plane (Figure 2) represents the simplest sliding mechanism. Generally slopes are found very less prone to this type of failure because the geometric conditions which triggered it to the failure are rarely satisfied.
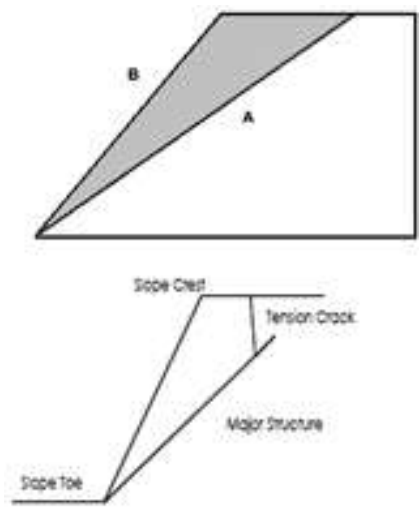

Figure 2: Typical view of Plane failure $(\mathrm{A}=$ Sliding plane, $\mathrm{B}=$ Slope face)

\subsection{Wedge failure}

A wedge failure of $\mathrm{OB}$ slope occurs when rock mass slides along two intersecting discontinuities, both of which dip out of the cut slope at an oblique angle to the cut face, thus forming a wedge-shaped block (Fig-3). Wedge failure can occur in rock mass with two or more sets of discontinuities whose lines of intersection are approximately perpendicular to the strike of the slope and dip towards the plane of the slope but this mode of failure requires that the dip angle of at least one joint intersect is greater than the friction angle of the joint surfaces and that the line of joint intersection intersects the plane of the slope.
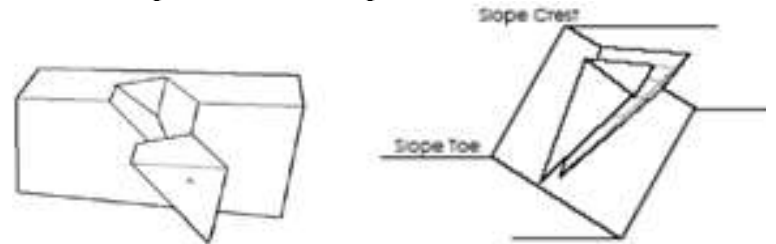

Figure 3: Typical view of wedge failure $(\mathrm{A}=$ wedge block $)$

\subsection{Toppling Failure}

A toppling failure of OB slope occur when columns of rock, formed by steeply dipping discontinuities in the rock rotates about an essentially fixed point at or near the base of the slope followed by slippage between the layers (Figure 4) but center of gravity of the column or slab must fall outside the dimension of its base in toppling failure. Jointed rock mass closely spaced and steeply dipping discontinuity sets that dip away from the slope surface are necessary prerequisites for toppling failure
This type of slope failure may be further categorized depend on the mode such as flexural toppling, block toppling, and block flexural toppling.
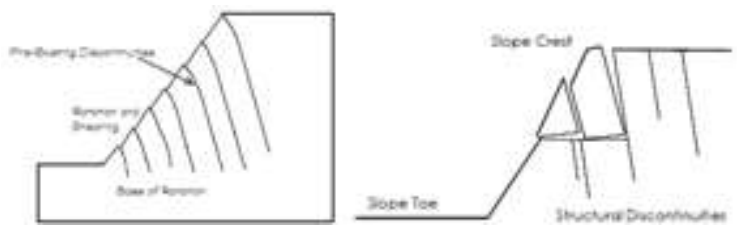

Figure 4: Typical view of toppling failure

\subsection{Circular Failure}

Circular failures generally occur in weak rock or soil slopes. This type of failure does not occur necessarily along a purely circular arc, some form of curved failure surface is normally apparent. Circular shear failures are influenced by the size and mechanical properties of the particles in the soil or rock mass.

Circular failure is grouped in three sorts (Figure 5) relying upon the region that is influenced by the failure surface.

4.4.1 Slope failure: In this sort of failure, the circular segment of the break surface meets the incline over the toe of the slant. It is on the grounds that when the incline point is high and the dirt near to the toe has the high quality.

4.4.2 Toe failure: In this sort of failure, the circular segment of the break surface meets the incline at the toe.

4.4.3 Base failure: In this sort of failure, the circular segment of the failure goes underneath the toe and into base of the incline. It happens when the incline edge is low and the dirt underneath the base is gentler and more plastic than the dirt over the base.

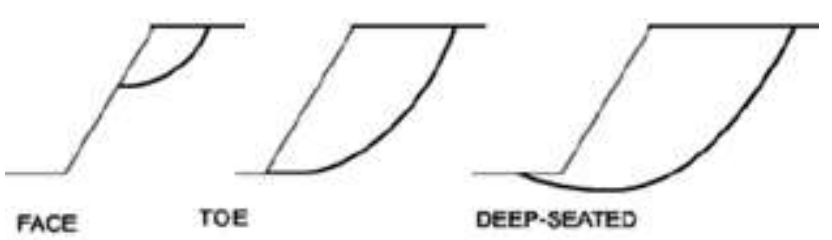

Figure 5: different types of circular failure

\section{Mechanism of stabilization of slope with fly ash}

Mixing overburden with fly ash improves the mechanical strength of dump as fly ash absorbs the moisture from clay as well as substantially increases the strength of the resultant mixture due to the pozzolanic properties of ash [10] because fly ash is pozzolanic, which means it's a siliceous or siliceous-and-aluminous material that reacts with calcium hydroxide to form a cement. When Portland cement reacts with water, it produces a hydrated calcium silicate (CSH) and lime. The hydrated silicate develops strength and the lime fills the voids. Properly selected fly ash reacts with the lime to form $\mathrm{CSH}$-the same cementing product as in Portland cement. This reaction of fly ash with lime in concrete improves strength. Cetin et al. [11] reported that the $\mathrm{CBR}$ value of the soil stabilized with fly ash $(10 \%$ and $20 \%)$ and lime kiln dust $(2.5 \%$ and $5 \%)$ were found to be 


\section{International Journal of Science and Research (IJSR) \\ ISSN (Online): 2319-7064}

Index Copernicus Value (2016): 79.57 | Impact Factor (2015): 6.391

69-142 after 7 days curing and greater than 164 after 28 days curing.

\subsection{Case Study of Gare Palma Open Cast Coal Mine}

Description- Gare Palma IV/ 1 open cast coal mine is in Gharghoda tahsil of Raigarh district of Chhattisgarh, India. The coordinates of this sub block are $22^{0} 05^{\prime} 46^{\prime \prime} \mathrm{N}$ to $22^{0}$ 07'54'N and 83 $31^{\circ}$ ' $44^{\prime \prime} \mathrm{E}$ to $83^{\circ} 34^{\prime} 04^{\prime \prime} \mathrm{E}$. The total lease area of the mine is 978.654 ha. The area in general is uneven and undulated ground and the north-east boundary is full of weathered rocks in the shape of small hillocks. It is an open cast coal mine operating in shovel-dumper technology. There are five workable coal seams in the block and thickness of the seams varies from 2 to $8 \mathrm{~m}$. The overburden comprises of mainly fine to coarse grained sand stone and shale. . The average stripping ratio of the mine is $1: 3.38$. The general strike of the sub-block beds of Barakar formation is North $30^{\circ}$ to $55^{\circ} \mathrm{W}$-South $30^{\circ}$ to $55^{\circ} \mathrm{E}$ dipping towards South west at an angle of $3^{0}-4^{0}$. The fly ash generated from the power plant was disposed in the mine by mixing in the overburden dump of the mine. There were two pits in the mine namely Pit 1 and Pit 2. Pit 1 was separated from Pit 2 by a runnel. Pit 1 is exhausted and working is being done in Pit 2. The void of the Pit 1 is being backfilled by admixture of fly ash overburden dump. A panoramic view of the Pit 1 is shown in Fig-6.



Figure 6: Panoramic view Pit 1 of Gare Palma IV/1 mine

Method of Dumping Fly-ash and OB- In the backfilling of mine void, initially a deck of $30 \mathrm{~m}$ height of over burden only was constructed along the floor of the pit. An embankment of about $15 \mathrm{~m}$ wide and $5 \mathrm{~m}$ high was then constructed all around the proposed area for fly ash overburden dump filling. There were formed many dumping areas in such a way that each area was separated by another dump area by a $15 \mathrm{~m}$ wide embankment. Fly ash is transported from Tamnar-based $2400 \mathrm{MW}$ power plant. A well-mixed admixture of fly ash and overburden, containing $25 \%$ fly ash and $75 \%$ overburden by volume was then filled in the area up to a height of $5 \mathrm{~m}$. Over the layer of fly ash overburden admixture, a $5 \mathrm{~m}$ thick layer of overburden was laid. In the same way, alternate layers of fly ash overburden admixture and overburden only was filled in the void. Thus, each layer of admixture of fly ash overburden was followed by a layer of overburden. For ensuring the safety of the dumps, backfilling was done in 4 decks each of $30 \mathrm{~m}$ height. Each deck contains 3 layers of admixture and 3 layers of overburden. The sides of the dumps were kept benched with slope angle of 28 degree. A layer of about $2 \mathrm{~m}$ thick top soil was spread at the top of the dumps, over which thick plantation of local species of plants was done. To prevent the fly ash becoming air borne, the dumps were so designed that every layer of fly ash overburden admixture was always encapsulated within a layer of overburden. Fly ash from the power plant and over burden from the external dump was transported to the filling site in $25 \mathrm{~T}$ dumpers. To maintain the correct ratio of fly ash and overburden, transportation of fly ash and overburden was such regulated that after every three trucks of overburden, one truck of fly ash is dumped in the void. The fly ash was mixed with overburden and compacted by dozers (Fig-7). The fly ash OB dump were found stable, no incident of slope failure occurred. The plantation done on the top of the dump to biologically stabilize the dumps was highly successful. A good growth of plants is noticed (Fig-8). The air, surface and ground water quality parameters monitored were also found within the prescribed limit.

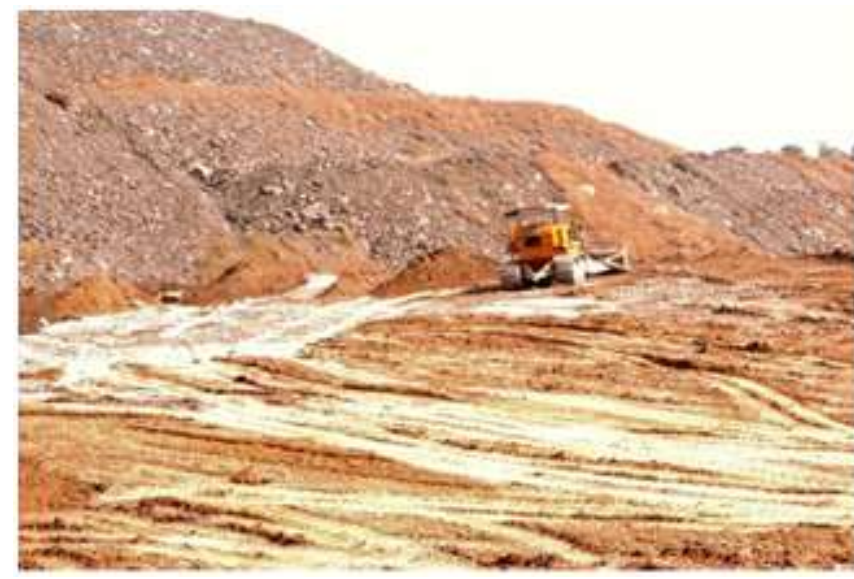

Figure 7: Spreading and compacting admixture of fly ash and overburden

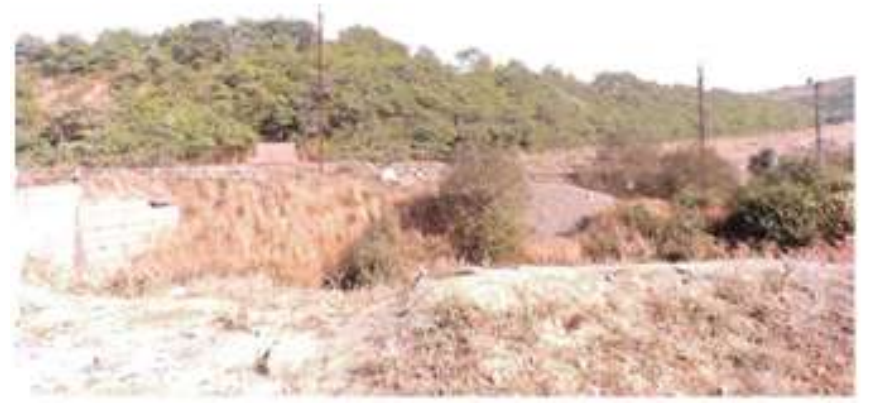

Figure 8: Plantation on the top of the dump.

\subsection{Case study on Jindal Power Opencast Coal mine}

Description-Jindal Power Open Cast Coal Mine is in the Tamnar tahsil of Raigarh district of Chhattisgarh state. The block is located between Longitudes - 83 $29^{\prime} 40^{\prime \prime}$ to $83^{\circ} 32^{\prime} 32^{\prime \prime}$ (E) and Latitude - $22^{\circ} 09^{\prime} 15^{\prime \prime}$ to $22^{\circ} 05^{\prime} 44^{\prime \prime}$ (N) falling in the toposheet number 64 N/12 (Survey of India). It is almost flat with small undulations from surface. The lithological near mine site comprises about 3-4 m unconsolidated loose soil/alluvium. There is weathered shale/sandstone up to 6-8 $\mathrm{m}$ depth below the top soil. The weathered shale and sandstone which is varies from 3 to 10 $\mathrm{m}$ having comparatively loose in nature so it can be excavated without blasting. After below weathered zone, the rock is compact, hard and massive in nature so it is

\section{Volume 6 Issue 12, December 2017}

\section{www.ijsr.net}




\section{International Journal of Science and Research (IJSR) \\ ISSN (Online): 2319-7064}

Index Copernicus Value (2016): 79.57 | Impact Factor (2015): 6.391

excavated after blasting. Thus the average depth of the excavation of these excavations is about $16 \mathrm{~m}$. Thermal power plants is a captive plant of Jindal Power Limited, Tamnar which have the capacity of 1000 MW. It is generated the fly ash nearly 16000 tons per day after burning of coal. Fly ash is being used at Jindal open cast coal mine by mixing with overburden material for backfilling in the mine voids according to guide lines of DGMS.

Method of Dumping Fly-ash and OB- Pond ash was being used to slope stabilization of backfilling as admixture in overburden in JPL mine. It was proposed before starting mining to have internal overburden dumps. Overall height of OB dumps has up to $120 \mathrm{~m}$ with four decks having maximum height of $30 \mathrm{~m}$ in each individual deck. Presently overburden dump height is about 72 meter with a maximum deck height up to $25 \mathrm{~m}$ in this mine. there was dumped a row of overburden before backfilling the admixture of fly ash with overburden all around the proposed area for fly ash dump to forming an embankment with a height up to $5 \mathrm{~m}$ and width of more than $15 \mathrm{~m}$. To separate each dump with another overburden dump, a number of such areas were formed in a layer wherein the fly ash was dumped in order to control the airborne quality of the fly ash. Fly ash was dumped within this area surrounded by overburden in alternate layers of height not exceeding $5 \mathrm{~m}$ in each layer. Therefore, each layer of overburden was followed by a layer of mixture of fly ash and overburden having mixture of $25 \%$ of fly ash and so on up to the height of $30 \mathrm{~m}$. Figure 9 shows cross section view of the dumping of fly ash. The side of the overburden dump is benched and sloped with an angle about $32^{\circ}$. Dump is compacted and width of the dump is about $40 \mathrm{~m}$. The overall slope of dump is about $27^{\circ}$ from the horizontal. Fig10 shows benches of mixture of overburden with fly ash.
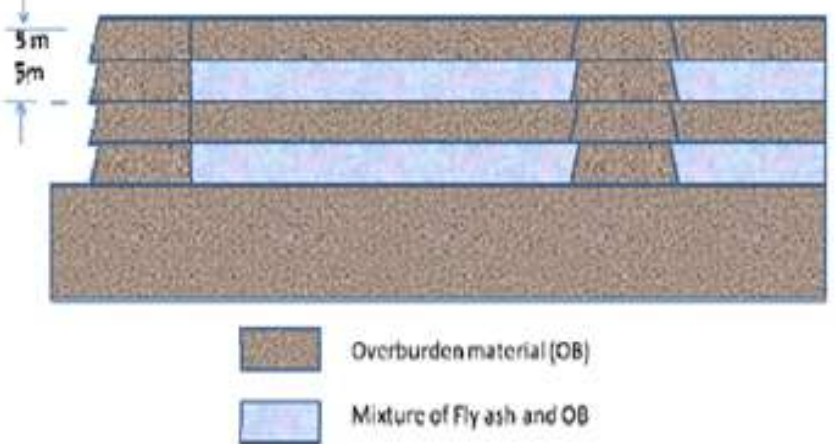

Figure 9: Cross section view of the dumping of fly ash

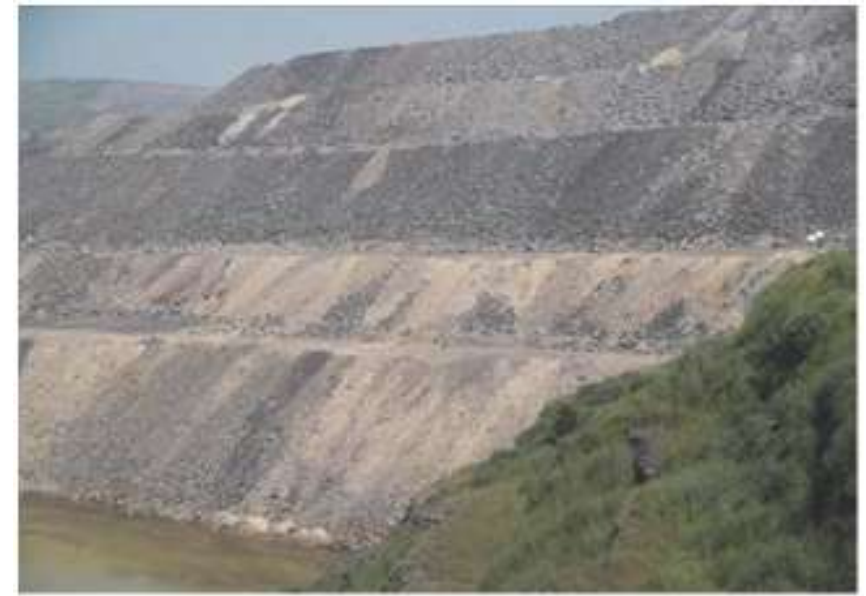

Figure 10: benches of mixture of overburden with fly ash

\subsection{Case Study of KTK Open Cast Coal Mine}

Description- KTK OC mine (SCCL) is located at a distance of $3 \mathrm{~km}$ from Bhupalapalli. It has a leasehold area of $336 \mathrm{ha}$. The maximum depth of workings in the mine is up to $85 \mathrm{~m}$. A total of 5 seams are being worked in the mine. Production started in 2009 with an annual target of 1.2 million tons of coal 13 million $\mathrm{m} 3$ of $\mathrm{OB}$ removal. The stripping ratio of the mine ranges from $1: 10$ to $1: 12$. The total production is interlinked and is being transported to Kakatiya Thermal Power Station (KTPP) Chelpur located on the Bhupalapalli Warangal PWD road at a distance of $15 \mathrm{~km}$ from the mine.

Method of Dumping Fly-ash and OB - Fly ash was being transported from to KTK open cast coal mine from Kakatiya thermal power station (KTPP) Chelpur. Fly ash was dumped through dumpers followed by dozing. The fly ash was dumped in between the OB heaps at the rate of $30 \%$ of the OB material approximately 3 trucks of $\mathrm{OB}$ and 1 truck of fly-ash. During dozing the OB and fly ash heaps, a nearly homogenous mixture was formed along the slope and it was progressed up to the boundary of the dump area.

\section{Conclusion}

Both fly ash and overburden dump material are cohesion less and non plastic material but when they are mixed in presence of water and consolidate for some time, it hardens and changes the shear strength behavior of the mixture. Reason behind the increase in the cohesion of the dumps after mixing fly ash with overburden is that fly ash has binding property due to which it holds the particles together and because the fly ash is softer and finer it offers less resistance against the relative motion of the particles that is why its angle of internal friction reduces after mixing fly ash. When we mix the fly ash with coal mine overburden dump material and compact it in presence of water resulted in complex shear strength behavior of the fly ash-OB mixture. After dumping with alternate layer of overburden and mixture of fly ash and overburden then dozing the topsoil of nearly $2-3 \mathrm{~m}$ thick at the top, the slope also found more stable with safety factor higher than normal overburden dumps. We should be protected the dumps against rainfall for the long term stability of the slope top soil by taking measures like plantation, geo-synthetics, or jute reinforcement. Thus fly ash as an admixture can be disposed with coal mine overburden in order to improve the stability of dumps without water and air pollution.

\section{References}

[1] Fly Ash Utilization-Present vision. Pinki Sankar, CSIRCentral Institute of Mining and Fuel Research. Dhanbad,

India. www.wbpcb.gov.in/html/icufa/PinkiSankar

[2] V. Kumar, M. Mathur, S. K. Sinha and S. Dhatrak, "Fly ash: an environment saviour," in Proc. Fly ash India 2005, New Delhi, 2005, pp. I 1.1-1.8.

[3] Central Electricity Authority ( CEA) report 2015-16, New Delhi.

[4] R. Ulusay, F. Arlkan, M.F. Yoleri, and D. Caglan, Engineering geological characterization of coal mine waste material and an evaluation in the context of

\section{Volume 6 Issue 12, December 2017}




\section{International Journal of Science and Research (IJSR) \\ ISSN (Online): 2319-7064}

Index Copernicus Value (2016): 79.57 | Impact Factor (2015): 6.391

back-analysis of spoil pile instabilities in a strip mine, SW Turkey, Eng. Geol. 40 (1995), pp. 77-101.

[5] Fytianos K, Tsaniklidi B, Voudrias E. Leachability of heavy metals in Greek fly ash from coal combustion. Environ Int 1998;24:477-86.

[6] Bhattacharjee U, Kandpal TC. Potential of fly ash utilization in India. Energy 2002;27:151-6.

[7] http://www.cbrienvis.nic.in/Database/properties.html (EVVIS Center on fly ash)

[8] Fly Ash India 2005 - International Congress

[9] Jaeger J.C., Cook N.G.W, Fundamentals of Rock Mechanics. Chapman \& Hall, Wiley, New York, $585 p p(1976)$

[10]E. Steiakakis, K. Kavouridis and D. Monopolis, "Large scale failure of the external waste dump at the south field lignite mine, Northern Greece," Engineering Geology, Vol. 104, pp. 269-279, 2009.

[11]B. Cetina, A.H. Aydilekb, and Y. Guneyc, Stabilization of recycled base materials with high carbon fly ash, Resour. Conservat. Recycl. 54 (2010), pp. 878-892.

[12] www.wikipedia.org

\section{Author Profile}

Kamlesh Sahu, Student at National Institute of Technology Raipur in Mining Engineering Department.

Pankaj Dewangan, Head of Department at National Institute of Technology Raipur in Mining Engineering Department. 